\title{
発育期における背筋力の解析
}

\author{
小林 啓 三* 小西 真 人* 宮 崎 義 憲** \\ 川村 武* 酒 井 敏 夫*
}

\section{ANALYSIS ON BACK STRENGTH ON GROWING STATE}

\author{
Keizoh Kobayashi, Masato Konishi, Yoshinori Miyazaki \\ TAKeshi KaWamura, and Toshio SakaI
}

\begin{abstract}
1) Children's data (10-18 years old) of back strength, height, grip strength and running long jump from data book of Japan Education Ministry (1964-1981) were analyzed. Back strength was mainly studied and was compared with other data (grip strength etc.). The groups with high average values for back strength at 10-14 years old did not necessarily show high values for back strength at 17 years old, or vice versa. Values for back strength at 10-14 years old were not significantly correlated with those at 17 years old.

2) Using the data from data book mentioned above, tension of deep back muscle

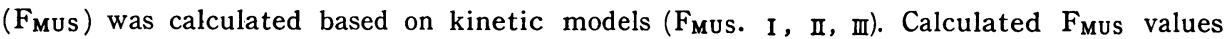
were 3-5 times larger than measured back strength values at each age.

3) Relative change of back strength and $F_{M U S}$ in 1964-1981 were compared. All values for back strength were lower than those for FMus except in 1967. During the late 1960 th and the 1970th, average back strength values gradully decreased, but the decrease of $F_{\text {MUS }}$ was less obvious than that of back strength.

4) Based on the data of 422 children (7-12 years old, male and femele), values of diaphragm area were approximated with some assumptions, and then $\mathbf{F}_{\mathbf{M U}}$ values were calculated. $F_{\text {MUS }}$ values calculated by approximate diaphragm area were significantly larger than those calculated by constant diaphragm area $\left(465 \mathrm{~cm}^{2}\right)$.

The figure for getting $F_{M U S}$ values easily was offered to avoid troublesome calculation. This consists of two graphs, and one can read $F_{M U S}$ values with reasonable precision. Parameters needed for getting $\mathrm{F}_{\mathrm{MUS}}$ values are sexuality, height, body weight and back strength.
\end{abstract}

(J. Physical Fitness Japan 1985, 34, Supplement : 1 7)

key words : back strength, deep back muscle tension, growing state.

\section{I. 緒}

発育期における青少年の体力を客観的に評価す べく，現在まで多くの測定が行なわれてきた，10 〜29歳の学童, 生徒, 学生拉よび青少年を対象と した「体力診断テスト」の成績が「体力・運動能 力調査報告書」として文部省体育局から発表され
ているが，これによれば1960年代後半から1970年 代にわたって各年龄の背筇力が逐年的に低下傾向 を示している. しかし，これらの測定值を資料と した分析が充分行なわれているとはいえないのが 現状である.そこで本研究では文部省資料を特に 背筋力について集団追跡的に解析し，また，背笳 力に対して体格の与える影響についてモデル計算

* 東京慈恵会医科大学第二生理 港区西新橋 3-25-8

** 東京学芸大学教育学部 保健体育学科 小金井市貫井北町4-1-1

Department of physiology, The Jikei University School of Medicine 3-25-8 Minato-ku, Tokyo 105 Department of helth and physical education, Tokyo Gakugei University 4-1-1 Nukuikitamachi, Koganei-shi, Tokyo 184 
を行なった.

\section{II. 方}

法

\section{A. 背筋力の集団追跡的観寮による分析}

「体力・運動能力調查報告 書」のうち, 「小学 校」「中学校」、「全日制高等学校」に分類されて いる10 17歳までの背筋力值を分析資料とした. 年度範囲としては，1964～1981年度に限った。 通常の観察方法は各年龄の測定值を年度を追っ て比較するものであるが，本研究では各年龄の測 定值を次年度の一歳上の年齢の測定值と関連づけ て各年代別に背筋力の発達を比較した。たとえ ば, 1970年度の10歳, 1971年度の11歳, 1972年度 の12歳‥1977年度の17歳の被験集団は同一ではな いが，同一年代であり，測定值はこの年代集団の 各年度に打ける代表值と考えられる。したがっ て，これらの測定值を追跡することにより，この 年代の背筋力発達曲線を集団追跡的に推測するこ とができる。

また, 背筋力, 身長, 握力, 走幅跳の各測定值 について，10１6歳の值と17歳の值との相関関係 を求めることにより，何歳の值が17歳の值に反映 するか，上記各項目で比較，検討した. この目的 で，年齢と各測定值との関係が線形であると仮定 し, 最小二乗法により回帰直線を決定し，相関係 数を求めた.

\section{B. 背筋力值に基づいた身体力学的モデル}

背筋力計によって測定された背筋力值は脊柱起 立筋の発生する力以外にも身体の種々の要素（座 高，体重など）により影響をらけることが予想さ れるが，これまでの分析においてはこれら脊柱起 立筋発生張力以外の要素はまったく考慮されてい ない，そこで，背筋力値（背筋力計による）と身 体の形態的数值から, 脊柱起立筋群の 発生張力 （F $\mathrm{F}_{\text {MUs }}$ ををデルによって計算し，形態的要素を 除いた筋張力が逐年的にどのように变化している か検討した. モデルは D. B. Chaffin"1ょよび J. M. Morris たち2l のものと同様であるが，変数の 算出方法により 3 種類の $\mathrm{F}_{\text {MUS }}$ を計算した.

計算に必要なパラメータは

体重
座高

$\mathrm{FH}$ ：背筋力測定値

BW : L5/S1 (第五腰椎と第一仙椎の関節)

より上の体幹, 頭頸部および上肢の

重量

$\mathrm{W}_{1}$ ：頭頸部と上肢の重量

$\mathrm{W}_{2}: \mathrm{L} 5 / \mathrm{S} 1$ より上の体幹の重量

B : BW の重心から L 5/S 1 までの水 平距離

$\mathrm{X}_{1} \quad$ : W 1 の重心から L 5 /S 1 までの 水平距離

$\mathrm{X}_{2}$ : W 2 の重心から L 5 / S 1 までの 水平距離

$\mathrm{H} \quad$ : 肩関節から L 5 /S 1 までの 水平距離

(1)〜(2)は文部省資料によった. (4)〜 (6)の数值に ついては D. B. Chaffin ${ }^{11}$, (7)〜10については C. E. Whitsett") の米国成人に打ける数值をもとに，文 部省資料の体重, 座高より換算して求めた。 なお, 上体前傾角度は $30^{\circ}$ とした。

また, 横隔膜面積, 春柱の中心と横隔膜の重心 との距離 $(\mathrm{M})$, 脊柱伸筋群の重心と耐柱の中心と の距離 $(\mathrm{A})$ は, 形態発育に伴ら変化が不明なた め,それぞれ $465 \mathrm{~cm}^{2}, 14 \mathrm{~cm}, 5 \mathrm{~cm}$ の成人值を もちいて定数とした. しかし，横隔膜面積につい ては後述するよらに身長から胸幅と胸厚を推定し て計算する方法を一部試みた。

脊柱起立筋群の発生張力 ( $\left.F_{\text {MUS }}\right)$ の計算式は,

$$
\mathrm{F}_{\mathrm{MUS}}=\frac{\text { (hip torque })-(\text { Fabdomen } \cdot \mathrm{A})}{\mathrm{M}}
$$

ただし Fabdomen=(Pabdomen $)$ ・ (diaphragm area)

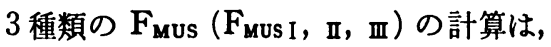

$\mathrm{F}_{\text {MUS I }}$ では

$$
\text { hip torque }=\mathrm{W}_{1} \cdot \mathrm{X}_{1}+\mathrm{W}_{2} \cdot \mathrm{X}_{2}+\mathrm{FH} \cdot \mathrm{H}
$$

Pabdomen $=10^{-4} \times[0.6516-0.005447 \times($ hip

$$
\text { angle) }] \cdot(\text { hip torque })^{1.8}
$$

F $_{\text {MUSII では }}$

hip torque $=\mathrm{BW} \cdot \mathrm{B}+\mathrm{FH} \cdot \mathrm{H}$ とし,

Pabdomen は J. M. Morris たち2)の背筋力

一腹圧関係により背筋力測定值から腹圧を求め 
て使用した.

$\mathrm{F}_{\text {MUSIII }}$ では

hip torque $=\mathrm{BW} \cdot \mathrm{B}+\mathrm{FH} \cdot \mathrm{H}$

Pabdomen $=10^{-4} \times[0.6516-0.005447 \times($ hip angle) $] \bullet(\text { hip torque })^{1.8}$ として,

前述の式により $\mathrm{F}_{\text {MUS }}$ を計算した。

hip angle は $30^{\circ}$ とした.

しかし，この方法では横隔膜面積を定数として おり，年齢による横隔膜面積增加を考慮していな い. そこで，横隔膜面積を形態計測值から推定す ることを試みた．計算に必要な測定値（身長・体 重・座高・背筋力など）は，東京学芸大学付属小 金井小学校, および小金井市立本町小学校の児童 男女 422 名（7 12歳）の実測值を用いた.

まず日本人の身長, 胸幅, 胸厚の測定値（男女 別, $7 \sim 12$ 歳 $)^{31}$ 上り, 身長一胸幅, 身長一胸厚の 回帰式を求め，身長の実測值から胸厚と胸幅を推 定する．次に，胸郭をだ円として，胸郭の断面積 を近似する. さらに胸郭断面積と横隔膜面積が比 例すると仮定して，米国成人の胸郭断面積／横隔 膜面積比を基に，先に求めた胸郭の断面積から横 隔膜面積を推定した. $F_{\text {MUS }}$ の計算は前述の $F_{\text {MUS I }}$ と同様の方法で行った.

\section{III. 結果}

\section{A. 集団追跡法的観察による分析結果}

集団追跡的観察により，10歳から17歳までの背 筋力の発達曲線を得た（図 1 ). 図は各年代集団の 1964～1981年度の背筋力平均值を結んだものであ る. 各年代集団の発達曲線の最初（最下部）のプ ロットが10歳時, 最後（最上部）のプロットが 17 歳時の値を示す.

17歳時の背筋力を年度を追って比較してみる と，1976年度に最低值を示しているが，この年代 集団の10歳時の值は他の年代と比較して低值では ないまた，1968～1972年度の10歳時の值は他の 年度に比し高值であるが，この年代集団の17歳時 の值はむしろ低值である.

このように10歳時の背筋力値は必ずしも17歳時 の値に反映しない，表 1 に各年代集団の10～16歳 時の值と17歳時の值との相関関係を身長, 背筋

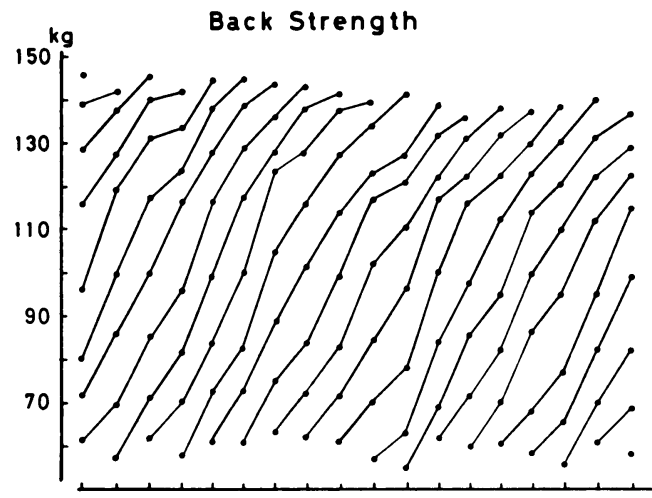

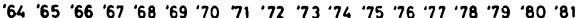

Fig. 1. Back strength development curve by years (Auther's chart based on the data from the Japan Education Ministry.)

Table 1. Correlation between physical performance at the age of 17 and at the age of 10 through 16 .

\begin{tabular}{|c|c|c|c|c|c|c|c|c|}
\hline & & 10 & 11 & 12 & 13 & 14 & 15 & 16 \\
\hline \multirow{4}{*}{$\sum_{\sum}^{\frac{0}{\pi}}$} & Height & + & + & + & + & + & + & + \\
\hline & Back Strength & - & - & - & - & - & + & + \\
\hline & Glip Strength & - & - & - & - & - & + & + \\
\hline & Running Long J. & - & - & - & - & - & 一 & + \\
\hline \multirow{4}{*}{ 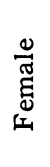 } & Height & + & + & + & + & + & + & + \\
\hline & Back Strength & - & - & - & - & - & + & + \\
\hline & Glip Strength & - & - & + & + & - & - & + \\
\hline & Running Long J. & - & - & - & + & - & + & + \\
\hline
\end{tabular}

$+: \mathrm{P}<0.1,-:$ non significont

力, 握力, 走り幅跳びの各項目について示した. 身長は男女とも10歳時と17歳時の值に 相 関があ り，10歳の時身長が高かった集団は17歳時に身長 が高い傾向にあることが示された．背筋力，握 力, 走り幅跳びについては，種目により，また性 別により相関関係のパターンは異なっていた．背 筋力においては男女とも15，16歳時の值のみ17歳 時の值と有意な相関を示し，10１4歳時の值では 有意な相関は認められなかった１7歳時の値と各 年齢の值との直線回帰式を求めると，男子の11 13歳，女子の12１3歳では，むしろ負の傾きを示 した.

\section{B. モデルによる分析結果}

文部省資料（10〜18歳，男子）を用いて，3つ の方法により求めた $F_{\text {MUS }}\left(F_{\text {MUS I }}\right.$, II, III) の成長 
に伴う変化を図 2 に示す. F $\mathrm{F}_{\mathrm{MLS} \text { I }}$, II, III の值は各年 齢で背筋力実測值の $3 \sim 5$ 倍の值であった. 10歳 時の背筋力測定值の平均は $59.9 \mathrm{~kg}$ であったが，

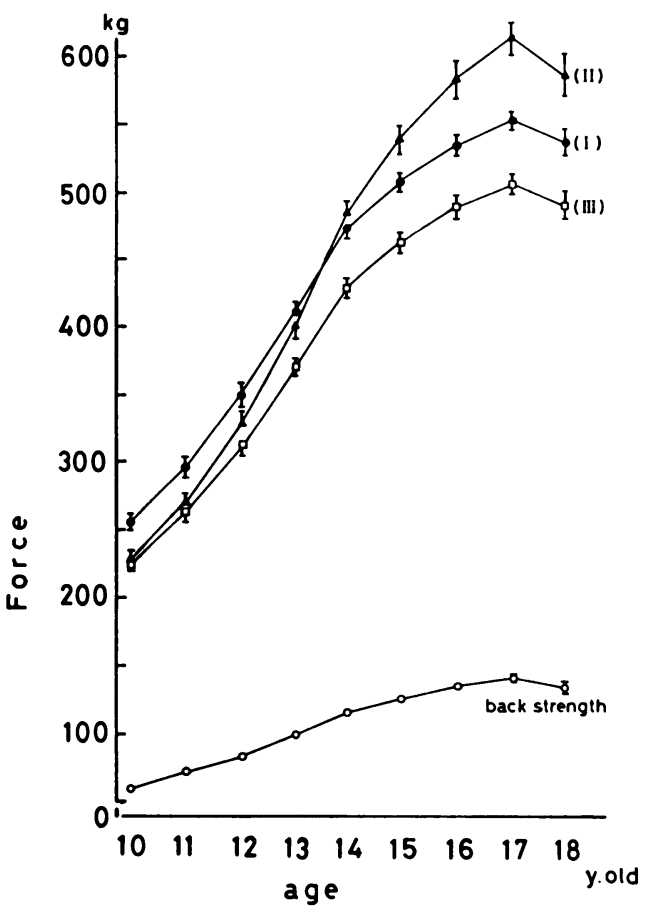

Fig. 2. Changes, by ages, of value of back strength and three kinds of calculated values of deep back muscle tension ( $F_{M U S}$ ).

(I) : F MUS I, (II) : F MUS II, (III) : F FUSIII
F

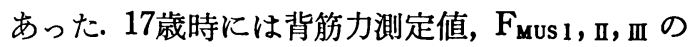
值は各々 $141.5,551.0,612.1,505.5 \mathrm{~kg}$ に增加し
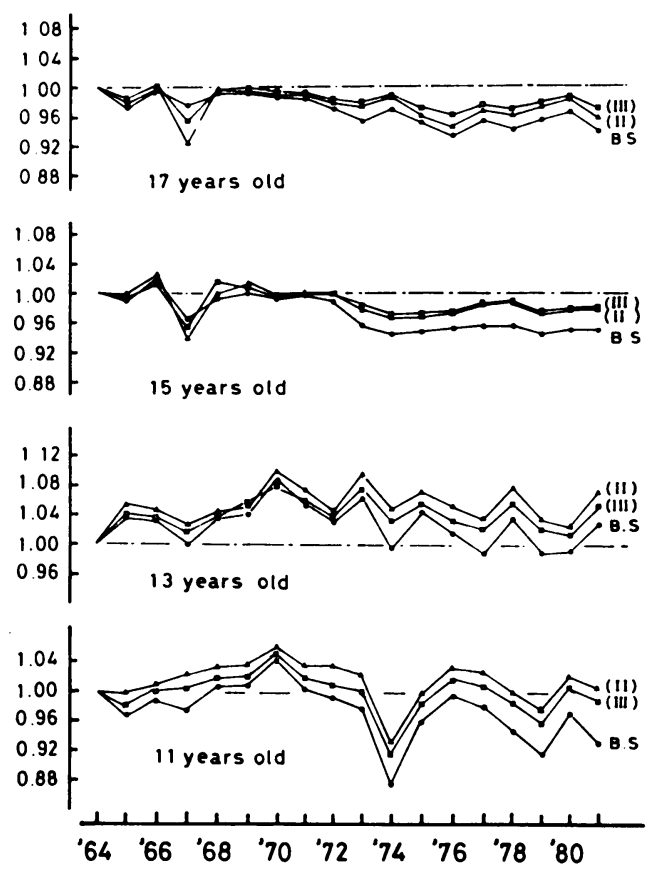

Fig. 3. Change of relative back strength by years.

B. S : back strength

II : F Fus II

III : F

Table 2. Calculated value of tension of deep back muscle (F $F_{\text {MUs). }}$

\begin{tabular}{|c|c|c|c|c|c|c|c|}
\hline \multicolumn{2}{|c|}{ AGE } & 7 & 8 & 9 & 10 & 11 & 12 \\
\hline \multirow{2}{*}{ NUMBER } & MALE & 31 & 41 & 35 & 40 & 34 & 37 \\
\hline & FEMALE & 31 & 38 & 35 & 34 & 35 & 31 \\
\hline \multirow{2}{*}{$\begin{array}{l}\text { DIAPHRAGM } \\
\text { AREA }\left(\mathrm{cm}^{2}\right)\end{array}$} & MALE & 159.3 & 168.2 & 175.8 & 183.2 & 193.5 & 201.5 \\
\hline & FEMALE & 146.8 & 154.1 & 165.1 & 174.9 & 184.9 & 193.0 \\
\hline \multirow{2}{*}{$F_{\text {MUS }}$} & MALE & 192.7 & 264.8 & 316.5 & 340.0 & 405.7 & 491.4 \\
\hline & FEMALE & 185.0 & 220.0 & 266.5 & 304.9 & 359.3 & 439.8 \\
\hline \multirow{2}{*}{$F_{\text {MUS I }}$} & MALE & 178.0 & 238.6 & 280.9 & 300.5 & 349.8 & 413.2 \\
\hline & FEMALE & 170.7 & 200.8 & 239.9 & 271.5 & 315.0 & 375.4 \\
\hline
\end{tabular}

Number : Number of subjects

F $_{\text {MUS }}$ : Each value is calculated by approximate diaphragm area.

F MUS I : Each value is calculated by constant diaphragm area $\left(465 \mathrm{~cm}^{2}\right)$.

Diaphragm area: Values are approxmated with some physical assumptions.

each value is expressed by mean. 
た. 加龄にともなう増加は, $\mathrm{F}_{\text {MUSII }}$ で最も顕著で あった.

背筋力と $\mathrm{F}_{\text {MUS }}$ が形態的要素 (距離と重量) に よりどのような影響を受けるか, 体重と背筋力 值, F MUS I，II，IIIの相関関係を調べた.

文部省資料17歳男子の体重之背筋力値の相関係 数を求めると, -0.678 となり, 有意 $(\mathrm{P}<0.01)$ な 負の相関が得られた.これに対し，体重と $F_{\text {MUS I }}$ ， II, III との相関係数は各々 $-0.245,-0.141,-0.245$ で有意な相関は認められなかった。

背筋力と $\mathrm{F}_{\text {MUS }}$ の逐年的変化を検討する目的
で，1964年度の背筋力， $F_{\text {MUSII III }}$ の 平均值をそ れぞれ 1 として，各年度の平均值を正規化し，年 秢別に比較した（図 3 ). その結果, 背筋力の相対

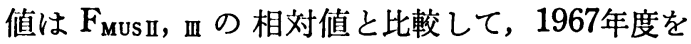
除き，すべて低值であった.

$7 \sim 12$ 歳の男女 422 名の実測値から, 横隔膜面 積の推定值を用いて $F_{\text {MUS }}$ を計算した（表 2 ). 得 られた $\mathrm{F}_{\mathrm{MUS}}$ は横隔膜面積を $465 \mathrm{~cm}^{2}$ で固定した 場合にくらべて，各年齢で高值を示した. 後者の 7 歳, 12 歳男子の 平均值が 各 々 $178.0,413.2 \mathrm{~kg}$ であったのに対し，前者では 192.7， $491.4 \mathrm{~kg}$ と
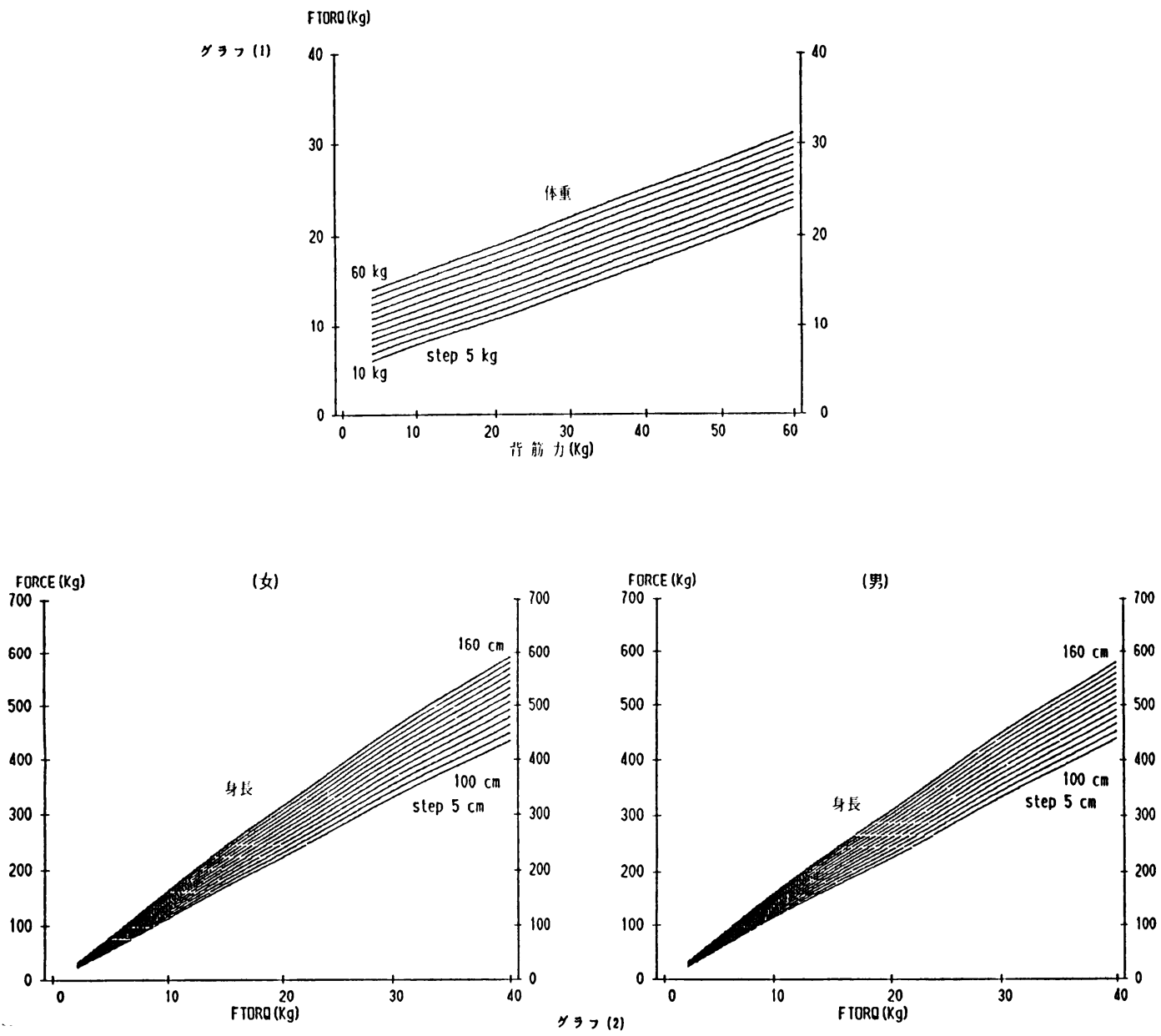

Fig. 4. Graph for calculation of values of tension of deep back muscle. Upward graph is for both male and female.

Left parts of downward graph is for male, righ for female. Weight is divided into $5 \mathrm{~kg}$ units, from $10 \mathrm{~kg}$ to $60 \mathrm{~kg}$.

Height is divided into $5 \mathrm{~cm}$ units, from $100 \mathrm{~cm}$ to $160 \mathrm{~cm}$. 
各々 $8.3 \%, 18.9 \%$ 高い值であった.

$\mathrm{F}_{\text {MUS }}$ の算出をさらに簡単にする目的で, $\mathrm{F}_{\text {MUS }}$ 読みとり用グラフを作製した(図 4). F Fus 計算に 必要な実測値 (背筋力, 体重, 座高) のらち, 座 高については 422 名について身長との相関を調べ たところ極めて高い相関（男子の相関係数 0.96, 女子の相関係数 0.93) が得られたので, 身長の実 測値から直線回帰式をもって計算することにし た.これは, 2つのグラフからなり, 身長, 体重, 性別, 背筋力値から $\mathrm{F}_{\mathrm{MUS}}$ を読みとることがでさ る. まずグラフ 1 で該当する体重曲線の背筋力值 （横軸）に拈けるFtorque (縦軸) を読みとる. 次 にグラフ 2(男女別) で該当する身長曲線の Ftorque 值に打ける Force 值（縦軸）を読みとれ ば，これが $\mathrm{F}_{\mathrm{MUS}}$ 值である. 座高を身長より求め ることによる誤差の標準偏差は 7 12歳の範囲で 最大 $\pm 10.9 \mathrm{~kg}$ であった. これは 7 歳, 12 歳男子 の $\mathrm{F}_{\mathrm{Mus}}$ 平均値の $5.7 \%, 2.2 \%$ に相当する.

\section{IV. 考察}

集団追跡法的手段により，17歳時の背筋力低下 を示す集団でも，10歳時の背筋力はむしろ高值で あった例もあることが明らかになった. 逆に10歳 で高い背筋力を示した集団でも，必ずしも17歳時 の背筋力が高いとはいえない.17歳時の背筋力に 有意の相関があるのは男女とも15，16歳だけで, それ以前でも負の相関係数をもつものもあった.

このことは, 小学校低学年から背笳力向上を目 指す指導をすることに対して疑問を投げかけるる のである．また，握力や走り幅跳びなどの異なる 運動能力では17歳時の值に有意な相関をもつ年龄 が運動種目や性別により異なっている.

このような結果は, 運動種目, 性別により指導 に適する時期が異なることを示唆するるのであ る。

計算により求められた脊柱伸筋群の張力 $\left(\mathrm{F}_{\text {MUS }}\right)$ は背筋力測定值の 4 倍程度の值を示した.つまり, 実際に測定される背筋力は筋の発生張力の一部で あり, 背筋力值の変化が必ずしも柱起立筋群の張 力変化を反映しているとはいえない.「体力・運 動能力調査報告書」に記載されている17歳時の背
筋力測定値（男子）は体重に対して有意な負の相 関を示したが， F られなかった. このように $\mathrm{F}_{\text {MUS }}$ の計算には身体 の形態的要素が考慮されているため, 身長, 体重 などの影響を除くことができると考えられる。

$\mathrm{F}_{\mathrm{MUS}}$ と背筋力值を逐年的に比較すると， $\mathrm{F}_{\text {MUS }}$ では背筋力にくらべ逐年的低下の幅は小さくなっ ている.このことから，1960年代後半から1970年 代にかけての背筋力の逐年低下傾向を論じている 意見は，やや過大評価されている感がある.

7 12歳の男女 422 名の測定值から横隔膜面積 を推定した結果, 横隔膜面積を $465 \mathrm{~cm}^{2}$ の定数と した場合にくらべて高值を示した.

各年龄の平均値は男子で最大 $18.9 \%$ ，女子で最 大 $17.2 \%$ 高い値であった. このことは， $465 \mathrm{~cm}^{2}$ といら横隔膜面積が, 日本人の青少年に比しはる かに体格のよい米国成人の值であり，横隔膜面積 が(前述の式からわかるように) $F_{\text {MUS }}$ に対して負 の要因であることからも予想されることである. 今回のモデルから推定した横隔膜面積は 7 歳, 12 歳男子の平均值で $159.3 \mathrm{~cm}^{2}, 201.5 \mathrm{~cm}^{2}$ で, これ は米国成人の值の各々 $34.3,43.3 \%$ にすぎない.

本研究のモデルに関しては, 横隔膜面積の算出 法, 身体各部の重量や距離の算出法などに多くの 改良すべき点があり, 今後の基礎データの蓄積が 必要と思われる.したがって，個人に対して本モ デルをそのまま適用することには，やや無理があ る、しかし，今回のように，限られた年龄範囲の 中での集団の動向を概観するらえでは，このモデ ルによって算出された（あるいはグラフから求め た） $\mathrm{F}_{\mathrm{MUS}}$ は有効な資料であると考える.

\section{V. 要 約}

1. 1964 1981年度の文部省「体力・運動能力 調查報告書」に記載されている10～17歳（一部18 歳）の測定值を分析資料とし，背筋力を主に，身 長, 握力, 走り幅跳びについても集団追跡法的観 察により分析を行なった. 背筋力では, 男女とも 10〜14歳時の值は17歳時の值と有意な相関を示さ ず，早い時期に背筋力の高いことが，必ずしも後 の背筋力に反映していないことが示された. 握 
力, 走り幅跳びでは, 17歳時の值と相関がある年 齢は性別により異った.

2. 文部省資料を用いて，モデル計算により， 脊柱起立筋群の発生張力 ( $\mathrm{F}_{\text {MUS }}$ )を推定した. $\mathrm{F}_{\mathrm{MUS}}$ の值は各年龄で背筋力実測值の $3 \sim 5$ 倍で あった.このことから，実際に測定される背筋力 は，脊柱起立筋の発生張力のごく一部であること が示唆された。 また, 背笳力値は体重などの形態 的要素の影響を受け，17歳男子の背筋力測定值は 体重と負の相関を示したが $F_{\text {MUS }}$ は体重と有意な 相関関係を示さなかった

3. 1964年度の値を 1 として, 背笳力値, $F_{M U S}$ の相対的変化を逐年的に比較すると，1967年度以 外のすべての年度において, 背筋力値の相対値は

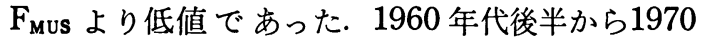
年代にかけての背筋力の低下傾向は $\mathrm{F}_{\mathrm{MUS}}$ では軽 微であった.

4. いくつかの仮定に基づいて, 横隔膜面積を 推定し, 7 12歳の男女 422 名について $\mathrm{F}_{\text {MUs }}$ を 算出した。この方法で計算した $\mathrm{F}_{\mathrm{MUS}}$ の值は，横 隔膜面積を $465 \mathrm{~cm}^{2}$ に固定した場合と比較して， すべての年龄で高值を示した．また， $F_{M U S}$ の算 出をさらに簡単にする目的で $\mathrm{F}_{\mathrm{MUS}}$ 読みとり用グ ラフを作製した.これは，2つのグラフからな
り， $\mathrm{F}_{\mathrm{MUS}}$ 読みとりに必要なパラメータは身長， 体重, 性別, 背筋力値である.

本研究は昭和 57 ～59年度文部省科学研究費「発 育期の体力に関する基礎的研究」によった（課 題番号, 昭和 57 年度 57123109 , 昭和 58 年度 $58124037 ，$ 昭和59年度59127034)

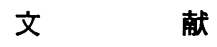

1) Chaffin, D. B.(1982): Low-back stresses during load fitting. In: Ghista, D. N., Human body dynamics., chap. 7, Clarendon Press., Oxford. 248-271.

2) Morris, J. M., Lucas, D. B. and Bresler, B. (1961) : Role of the trunk in stability of the spine. J. Bone and Joint Surg., Am. Vol., 43, 327-351.

3) 東京都立大学身体適性学研究室編. 日本人の体力標 準値, 不味堂出版, 東京.

4) Whitsett, C. E., Jr. (1963) : Some dynamic response characteristics of weightless man., AMRLTDR-63-18, Aerospace Medical Research Labs., Wright-Patterson AFB, Ohio, Apr. (Roth, E. M. 編, 横堀栄, 長沢有恒訳, 人体測定および時間, 空間的環境，人間-環境系 (下巻) 15 章，人間と技 術社, 東京, 1251-1362より引用] 